\title{
An estimate of the duration of the faunal change at the Cretaceous-Tertiary boundary
}

\author{
ABSTRACT \\ A detailed analysis of sedimentation rates in the Upper \\ Cretaceous-Paleocene section of pelagic limestones at Gubbio, \\ Italy, based on the previously reported correlation of Gubbio \\ magnetozones with the calibrated sequence of marine magnetic \\ anomalies, suggests that the faunal overturn in planktonic forami- \\ nifera at the Cretaceous-Tertiary boundary may have happened \\ rapidly, on the order of $10,000 \mathrm{yr}$ or less.
}

An episode of drastic faunal change is recorded at the close of the Cretaceous Period and is characterized by the seemingly abrupt, possibly synchronous worldwide disappearance of a major group of marine and terrestrial organisms, particularly the dinosaurs, flying reptiles, great marine reptiles, ammonites, belemnites, a variety of marine phytoplankton and zooplankton, and many others. In many if not most stratigraphic sections, the apparent abruptness in the change of fossil biota from Cretaceous to Tertiary could be attributed to an imperfect stratigraphic record. That is, in most such sections there is a break in the continuity of sedimentation near the boundary, so that the biostratigraphic boundary is within an unconformity representing an imprecisely known length of time. Although the sedimentary record across the Cretaceous-Tertiary boundary may appear to be continuous in some sections, it is nevertheless difficult to prove that it is so, depending on the degree of time resolution one attempts to attain. Certain geologic events (for example, the accumulation of a volcanic ash layer) are known to have occurred very rapidly, but others are usually considered so only in a more relative sense (that is, in comparison to the amount of time since the event transpired), largely because of the lack of adequate present-day analogs and of the decreasing time resolution with increasing age inherent in most of the current dating techniques. Perhaps the marked faunal turnover at the Cretaceous-Tertiary boundary falls in this latter category, yet a fairly precise knowledge of its duration could provide some insight into its cause. What limits can therefore be placed on the interval of time during which this event occurred?

On the basis of available isotopic age data, the CretaceousTertiary boundary lies near to 65 m.y. B.P., with an estimated uncertainty of 1 m.y. or perhaps 2 m.y. (Van Hinte, 1976). If the various isotopic age determinations compiled by Van Hinte are assumed to represent estimates of the boundary itself, which is of zero duration, then the uncertainty in the age merely reflects errors in the dating technique(s). In reality, the boundary is not dated directly; rather, samples for dating studies are obtained stratigraphically near the level at which the boundary is thought to be. Consequently, the amount of time represented by an uncomformity that may be associated with the boundary will also contribute to the uncertainty in its age. For this reason, the estimated uncertainty of 1 or $2 \mathrm{~m}$.y. for the date of the CretaceousTertiary boundary can be considered a maximum limit to the length of time represented by the apparent break in the fossil

\author{
D. V. Kent \\ Lamont-Doherty Geological Observatory \\ Palisades, New York 10964
}

succession. In the light of the magnitude of experimental errors, typically a few percent of the calculated age, it is unlikely that isotopic age dating alone can resolve the duration of this event better than this.

The results of a recently reported lithostratigraphic, biostratigraphic, and magnetostratigraphic study of an essentially complete section of Upper Cretaceous to Paleocene pelagic calcareous sediments exposed at Gubbio, Italy (Álvarez and others, 1977) suggest an indirect method of estimating the length of time represented by the faunal event at the Cretaceous-Tertiary boundary that is relatively insensitive to the accuracy and precision of absolute age determination. The Gubbio section is thought to be complete across the boundary, because the highest recognized planktonic foraminifera zone of the Maestrichtian (Abathomphalus mayaroensis zone) and the lowest recognized planktonic foraminifera zone of the Paleocene (Globigerina eugubina zone) are present here in stratigraphic succession (Premoli Silva, 1977). This does not imply, however, that these zones are present in their entirety here. Magnetic studies have delineated zones of normal and reversed magnetization polarities within the section, and these zones have been correlated to the calibrated sequence of marine magnetic anomalies (Lowrie and Alvarez, 1977; Roggenthen and Napoleone, 1977). The Cretaceous-Tertiary boundary, as recognized by the planktonic foraminifera present, was found in polarity zone Gubbio G-, which is correlated to the reversed interval between anomalies 29 and 30 of the magnetic-reversal time scale (Alvarez and others, 1977).

According to the most recent calibration of marine magnetic anomalies (La Brecque and others, 1977), this reversed interval represents $470,000 \mathrm{yr}$. This estimate of its duration is dependent on the degree of linearity of the magnetic-reversal sequence and on the ages chosen for its calibration. The former is based on the assumption of a constant rate of sea-floor spreading in a given region of the ocean. The relative widths of the polarity intervals corresponding to anomalies 29 to 34 , as determined from North Pacific profiles that were selected for the magnetic-reversal standard sequence, were shown to give an internally consistent pattern of sea-floor spreading in the world's ocean during this time (Cande and Kristoffersen, 1977). This suggests that the calibrated sequence of marine magnetic anomalies closely approximates a linear time sequence, even though error limits are difficult to define. Assuming a linear chronology uncertainty in the ages used for calibration proportionally affects 


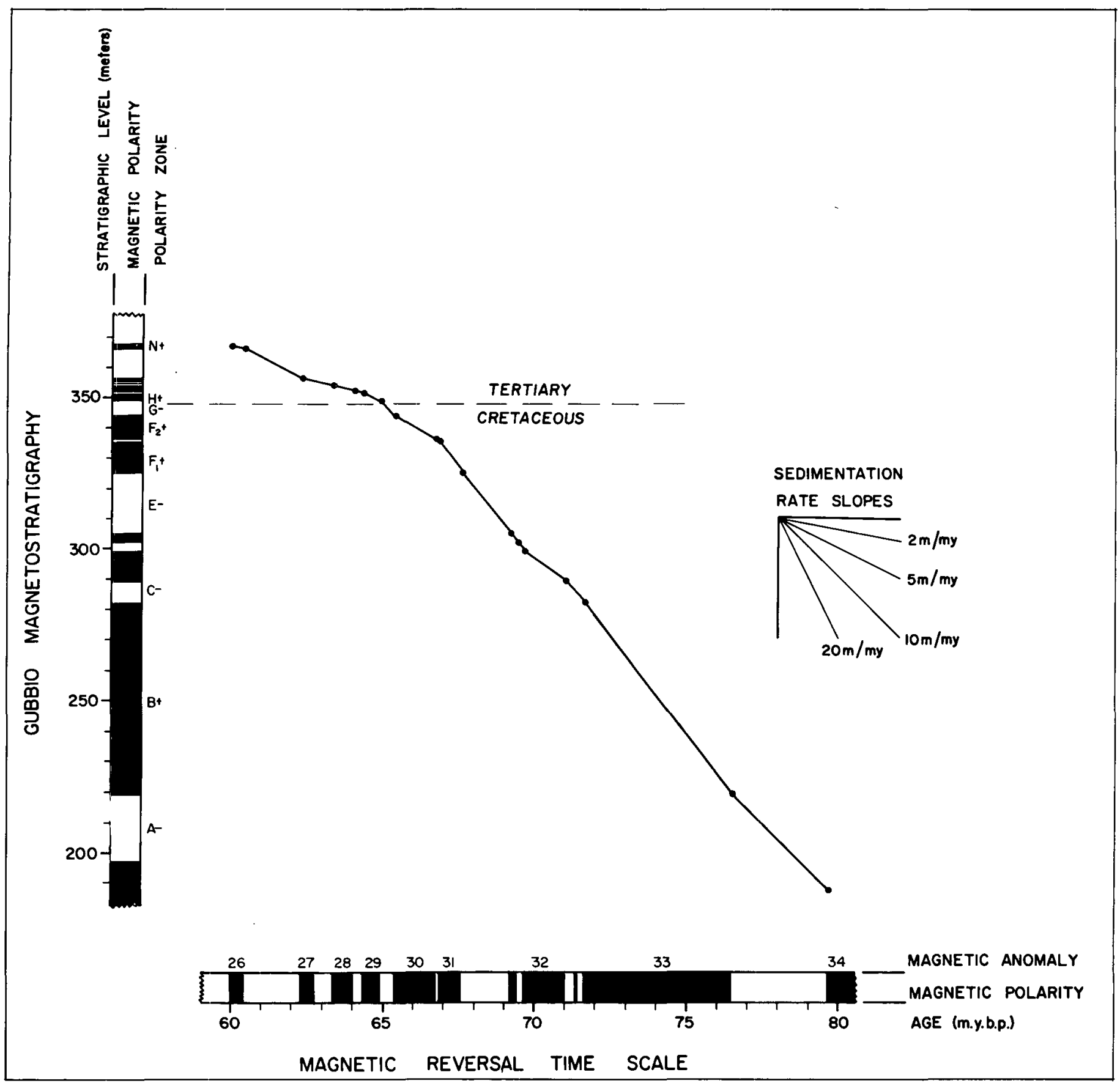

Figure 1. Sedimentation rates in Upper Cretaceous-Paleocene stratigraphic section of Scaglia Rossa at Gubbio, based on correlation of magnetic polarity zones in section (Alvarez and others, 1977; Lowrie and Alvarez, 1977; Roggenthen and Napoleone, 1977) to revised geomagnetic reversal time scale, based on calibrated sequence of marine magnetic anomalies (La Brecque and others, 1977). Shaded parts of polarity columns refer to normal magnetic polarity and unshaded part to reversed magnetic polarity. Stratigraphic level of Cretaceous-Tertiary boundary, base of Maestrichtian (at $270.2 \mathrm{~m}$ ), and base of Campanian (at $196 \mathrm{~m}$ ) determined by Premoli Silva (1977).

the age estimates for duration of magnetic polarity intervals. For example, if the age of 64.9 m.y. assigned to the base of anomaly 29 (La Brecque and others, 1977) is uncertain even by $\pm 5 \%$ (more than the estimated uncertainty in the age of the Cretaceous-Tertiary boundary), then the duration of the reversed interval between anomalies 29 and 30 would be in error by only $23,500 \mathrm{yr}$. In other words, this indirect dating method of correlation to the magnetic-reversal time scale can be used advantageously to determine the duration of relatively short time intervals with a high degree of precision for sedimentation-rate analysis.
The stratigraphic positions of magnetic polarity zones in the Gubbio section are plotted against the correlative portion of the magnetic time scale (Heirtzler and others, 1968, as modified by La Brecque and others, 1977) in Figure 1. The calculated sedimentation rate (for the consolidated rock) decreased from an average of about $10 \mathrm{~m} / \mathrm{m}$.y. through the Campanian and Maestrichtian sequence to about $4 \mathrm{~m} / \mathrm{m} . \mathrm{y}$. in the Paleocene sequence. This decrease in apparent sedimentation rate most likely reflects an overall change in lithology in an otherwise continuously deposited sequence (Arthur and Fischer, 1977), although 
it is quite possible that variations in sedimentation rate calculated for shorter time intervals can be due to intermittent diastems, resulting from hiatuses in deposition or diagenetic dissolution of carbonate. However, the presence in the section of the Gubbio G- magnetic zone, within which lies the CretaceousTertiary boundary, obviously shows that any time gap near or at the boundary must be less than the duration of the correlative geomagnetic reversed interval, or about $470,000 \mathrm{yr}$. In fact, it is apparent that there was not even a marked change in sedimentation rate in the Gubbio G- magnetic zone compared to the adjoining parts of the section, implying that sediment accumulation was, to a good approximation, uniform. On the scale considered here, the highest sedimentation rate $(14.9 \mathrm{~m} / \mathrm{m} . \mathrm{y}$.) occurs in the Gubbio $F_{1}+$ magnetic zone, whereas the calculated sedimentation rate for the Gubbio G- magnetic zone is $12.8 \mathrm{~m} / \mathrm{m}$.y. If it is hypothesized that the limestone now present in Gubbio G- was actually deposited at the highest average rate observed in the section, then about $1 \mathrm{~m}$ of section, or $70,000 \mathrm{yr}$ of record, could be missing. On the other hand, because the average sedimentation rate in Gubbio G- is near to and, in fact, greater than in the magnetic zones stratigraphically immediately below as well as above suggests that sediment accumulation was continuous and, hence, that little time is not represented in this part of the section.

On a finer scale, Arthur and Fischer (1977) described this part of the section as an alternation of more massive limestones and shaly interbeds of lesser thickness; geochemical studies suggest that the time represented by a bedding couplet is divided about equally between the thin shaly phase and the thicker calcareous phase. Thus, the calculated sedimentation rates shown in Figure 1 are an integrated average of the relatively rapidly deposited limestone beds and the more slowly deposited shaly interbeds. The limestone beds in Gubbio G- are reported to be on the average greater than $25 \mathrm{~cm}$ thick (Arthur and Fischer, 1977), so that each couplet represents $20,000 \mathrm{yr}$ and more of record. Therefore, about one-half this value, or $10,000 \mathrm{yr}$, is the order of maximum resolution possible in estimating the time separation across the Cretaceous-Tertiary boundary as it occurs in the Gubbio section.

From the assumptions above, it can be concluded that the duration of a major faunal event correlated to the CretaceousTertiary boundary in pelagic limestones of the Scaglia Rossa at Gubbio, Italy, is likely to be quite short, possibly on the order of 10,000 yr. Thus, it appears that the replacement of almost all Cretaceous planktonic foraminifera by typical earliest Paleocene forms was indeed abrupt, reflecting a small amount of elapsed time rather than a significant hiatus in the stratigraphic record.

Numerous mechanisms have been proposed to explain mass extinctions in general and at the end of the Cretaceous Period in particular (see Newell, 1967). The apparent rapidity in the overturn of planktonic foraminifera at the Cretaceous-Tertiary boundary might seem to favor a catastrophic cause, although some slower change reaching a critical threshold could produce a similar effect. Moreover, because the stratigraphic correlation of the foraminiferal zones at Gubbio with Upper Cretaceous and Paleocene stages defined on the basis of different fossil groups elsewhere is not yet precisely known (Premoli Silva, 1977), it is possible that a fine structure or detailed sequence, yet to be fully explored, may in fact characterize the faunal crises; this would require a more complex explanation of the underlying causal mechanism. For example, Butler and others (1977) presented evidence from the San Juan Basin of New Mexico suggesting that the Cretaceous-Tertiary boundary, based upon the last occurrence of dinosaurs, is significantly younger than in the marine deposits at Gubbio. The last occurrence of dinosaurs in this terrestrial section is within the upper part of a normal polarity zone that they correlate with anomaly 29 of the magnetic-reversal time scale; after a barren interval, this is followed by the first occurrence of Paleocene mammal fossils within the succeeding reversed polarity zone (between anomalies 28 and 29). The CretaceousTertiary boundary identified by Butler and others (1977), therefore, lies somewhere within the barren interval and is at least about 500,000 yr younger than at Gubbio.

If this temporal sequence of events is corroborated, the explanation of the faunal change at the end of the Cretaceous Period should lie in a process that initially and rapidly affected the marine faunal realm and only later, perhaps indirectly, caused the crisis in the terrestrial fauna. The Cretaceous-Tertiary boundary is not coincident with a geomagnetic polarity transition in the Gubbio section, thus eliminating an explanation based on any simple relationship between the faunal change and possible effects on organisms of a reversal of the Earth's magnetic field (Uffen, 1963). Although further speculation on the nature of the critical process may not be warranted on the basis of the available data, the expansion of this data base to place the Cretaceous-Tertiary boundary as identified elsewhere in the precise relative time framework that can be provided by magnetostratigraphic correlations should eventually give additional important constraints on the causal mechanism.

\section{REFERENCES CITED}

Alvarez, W., Arthur, M. A., Fischer, A. G., Lowrie, W., Napoleone, G., Premoli Silva, I., and Roggenthen, W. M., 1977, Upper CretaceousPaleocene magnetic stratigraphy at Gubbio, Italy. V. Type section for the Late Cretaceous-Paleocene geomagnetic reversal time scale: Geol. Soc. America Bull., v. 88, p. 383-389.

Arthur, M. A., and Fischer, A. G., 1977, Upper Cretaceous-Paleocene magnetic stratigraphy at Gubbio, Italy. I. Lithostratigraphy and sedimentology: Geol. Soc. America Bull., v. 88, p. 367-371.

Butler, R. F., Lindsay, E. H., Jacobs, L. L., and Johnson, N. M., 1977 , Magnetostratigraphy of the Cretaceous/Tertiary boundary in the San Juan Basin, New Mexico: Nature, v. 267, p. 318-323.

Cande, S. C., and Kristoffersen, Y., 1977, Late Cretaceous magnetic anomalies in the North Atlantic: Earth and Planetary Sci. Letters (in press).

Heirtzler, J. R., Dickson, G. O., Herron, E. M., Pitman, W. C. III, and Le Pichon, $X ., 1968$, Marine magnetic anomalies, geomagnetic field reversals, and motions of the ocean floor and continents: Jour. Geophys. Research, v. 73, p. 3119-3136.

La Brecque, J. L., Kent, D. V., and Cande, S. C., 1977, Revised magnetic polarity time scale for the Late Cretaceous and Cenozoic: Geology, v. 5, p. 330-335.

Lowrie, W., and Alvarez, W., 1977, Upper Cretaceous-Paleocene magnetic stratigraphy at Gubbio, Italy. III. Upper Cretaceous magnetic stratigraphy: Geol. Soc. America Bull., v. 88, p. 374-377.

Newell, N. D., 1967, Revolutions in the history of life: Geol. Soc. America Spec. Paper 89, p. 63-91.

Premoli Silva, I., 1977, Upper Cretaceous-Paleocene magnetic stratigraphy at Gubbio, Italy. II. Biostratigraphy: Geol. Soc. America Bull., v. 88 , p. 371-374.

Roggenthen, W. M., and Napoleone, G., 1977, Upper CretaceousPaleocene magnetic stratigraphy at Gubbio, Italy. IV. Upper Maastrichtian-Paleocene magnetic stratigraphy: Geol. Soc. America Bull., v. 88, p. 378-382.

Uffen, R. J., 1963, Influence of the earth's core on the origin and evolution of lfe: Nature, v. 198, p. 143-144.

Van Hinte, J. E., 1976, A Cretaceous time scale: Am. Assoc. Petroleum Geologists Bull., v. 60, p. 498-516.

\section{ACKNOWLEDGMENTS}

Reviewed by Walter Alvarez. Supported by National Science Foundation Grant EAR75-18955. L. H. Burckle, J. C. Liddicoat, N. D. Opdyke, and $\mathrm{T}$. Saito critically read the manuscript.

Contribution No. 2569, Lamont-Doherty Geological Observatory.

MANUSCRIPT RECEIVED JUNE 9, 1977

MANUSCRIPT ACCEPTED SEPTEMBER 26, 1977 